OPEN ACCESS

Edited by:

Göran Åke Olof Birgersson, Swedish University of Agricultural

Sciences, Sweden

Reviewed by:

Guy Smagghe,

Ghent University, Belgium

Yuan-Xi Li,

Nanjing Agricultural University, China

*Correspondence:

Shaoli Wang

wangshaoli@caas.cn

${ }^{\dagger}$ These authors have contributed equally to this work.

Specialty section:

This article was submitted to

Invertebrate Physiology,

a section of the journal

Frontiers in Physiology

Received: 25 June 2017 Accepted: 06 November 2017 Published: 22 November 2017

Citation:

Liu X, Chen G, Zhang Y, Xie W, Wu Q and Wang $S$ (2017) Virus-Infected Plants Altered the Host Selection of Encarsia formosa, a Parasitoid of Whiteflies. Front. Physiol. 8:937. doi: 10.3389/fphys.2017.00937

\section{Virus-Infected Plants Altered the Host Selection of Encarsia formosa, a Parasitoid of Whiteflies}

\author{
Xin Liu ${ }^{1 \dagger}$, Gong Chen ${ }^{2 \dagger}$, Youjun Zhang ${ }^{1}$, Wen Xie ${ }^{1}$, Qingjun Wu ${ }^{1}$ and Shaoli Wang ${ }^{1 *}$ \\ 1 Department of Plant Protection, Institute of Vegetables and Flowers, Chinese Academy of Agricultural Sciences, Beijing, \\ China, ${ }^{2}$ College of Plant Protection, Hunan Agricultural University, Changsha, China
}

The sweetpotato whitefly Bemisia tabaci (Gennadius) is one of the most invasive pest species worldwide. $Q$ and $B$ biotypes are the two most devastating species within the B. tabaci complex. Bemisia tabaci can vector hundreds of plant viruses that seriously threaten crop production. Endoparasitoid, Encarsia formosa Gahan, is widely used to control whiteflies, however, little is known about the effects of virus-infected plants on E. formosa parasitism of $B$. tabaci. Here, we reported that tomato, which was infected with Tomato Yellow Leaf Curl Virus (TYLCV), altered the host selection of E. formosa between $B$. tabaci $Q$ and $B$ biotypes. On healthy tomato plants, parasitism and host selection by $E$. formosa did not differ between the 3rd-instar nymphs of $B$. tabaci $Q$ and B biotypes. On TYLCV-infected tomato plants, however, B. tabaci $Q$ biotype were significantly more attractive to $E$. formosa than B biotype. When TYLCV-infected tomato plants were infested with $B$. tabaci $Q$ or $B$ biotype, volatile profiles differed quantitatively but not qualitatively. Olfactometer assays suggested that the preference of $E$. formosa to $Q$ over $B$ biotype was associated with an elevated level of $\beta$-Myrcene, $\beta$-Ocimene, $\beta$-Caryophyllene, and $\alpha$-Humulene from TYLCV-infected tomato plants.

Keywords: Encarsia formosa, Bemisia tabaci, tomato yellow leaf curl virus, host selection, plant volatiles

\section{INTRODUCTION}

Parasitoid wasps, during foraging, may encounter various and multiple situations or factors, such as insect species and these insect-borne pathogens; this would make the parasitoids foraging more complicated and difficult (Ponzio et al., 2013, 2016a; Li et al., 2014; Martini et al., 2014; Mauck et al., 2015). Hence, finding a reliable and efficient way to locate their suitable host is important for their propagation. Numerous evidences have indicated that the pathogen, herbivory or ovipositioninduced plant volatiles are important infochemicals and reliable indicators to many parasitoid species for seeking and locating their hosts (McCormick et al., 2012; Li et al., 2014; Martini et al., 2014; Mauck et al., 2015; Ponzio et al., 2016a,b). These chemical volatiles thus have an important role for the host searching, location and discrimination behaviors of carnivores (McCormick et al., 2012; Li et al., 2014; Ponzio et al., 2016a,b).

The sweetpotato whitefly, Bemisia tabaci is an important insect pest on many vegetables and other agricultural crops. The $\mathrm{Q}$ and $\mathrm{B}$ biotypes are two most invasive and destructive cryptic species of B. tabaci in China (De Barro et al., 2011; Pan et al., 2012; Zheng et al., 2017). Serious damage by B. tabaci results not only from its removal of plant sap and secretion of honeydew (which causes sooty mold) but also from its transmission of various begomoviruses (De Barro et al., 2011). The 
only known vector of Tomato yellow leaf curl virus (TYLCV), which is a typical begomovirus, is B. tabaci, and B. tabaci transmits TYLCV in a persistent manner (Brown and Czosnek, 2002; Jones, 2003). A recent study found that TYLCV transmission efficiency is higher for the Q biotype than for the $\mathrm{B}$ biotype (Ning et al., 2015). Although the Q biotype has replaced the $\mathrm{B}$ biotype in many areas of China over the past decades (Pan et al., 2011), the two biotypes continue to coexist in some locations (Chu et al., 2010a,b; Teng et al., 2010; Pan et al., 2012; Zheng et al., 2017).

Encarsia formosa Gahan is a cosmopolitan and commercially important parasitoid of B. tabaci and other whiteflies, and has been widely used to reduce whitefly damage to crops (Gerling et al., 2001; Grille et al., 2012; Liu et al., 2015, 2016). Parasitism of B. tabaci by E. formosa is affected by the developmental stage of Q and B biotypes (Liu et al., 2016) and may also be affected by infection of host plants by TYLCV (Liu et al., 2014). In the latter case, parasitism of $\mathrm{Q}$ biotype nymphs was higher on TYLCV-infected tomato plants than on TYLCV-free plants, but parasitism of B biotype nymphs did not significantly differ on TYLCV-infected vs. TYLCV-free tomato plants (Pan et al., 2013, 2014; Liu et al., 2014). These studies suggested that the selection of B. tabaci biotype Q and B as hosts by E. formosa may differ and may be affected by TYLCV infection of plants. Additional research is needed to determine how parasitism and host selection by E. formosa differs between the two important biotypes of $B$. tabaci and how such selection and parasitism is affected by TYLCV infection of host tomato plants.

The first objective of the present study was to further describe how host selection by E. formosa differs between B. tabaci Q and $B$ biotypes and how host selection is affected by TYLCV infection of tomato plants. A second objective was to determine potential mechanisms underlying the effects of biotype and TYLCV infection of tomato on such host selection.

\section{MATERIALS AND METHODS}

\section{Plant and Insect Materials}

Lycopersicon esculentum (variety "No. 9 Zhongza") tomato plants were grown in plastic pots $(7 \mathrm{~cm}$ diameter) containing a mixture of peat moss, vermiculite, organic fertilizer, and perlite in a 10:10:10:1 ratio by volume (Shi et al., 2013). Tomato plants with three to four expanded leaves were inoculated with a TYLCV infectious clone kindly provided by Professor Xueping Zhou (Institute of Plant Protection, Chinese Academy of Agricultural Sciences, Beijing, China); infection by TYLCV was confirmed as previously described (Ghanim et al., 2007; Shi et al., 2013; Liu et al., 2014). TYLCV-free plants were not inoculated with the virus. Plants with six to eight fully expanded leaves were used for the assays and experiments described in the following sections.

Laboratory colonies of B. tabaci biotype Q and B, whose identities was periodically confirmed based on the cleavage amplified polymorphic sequence (CAPS) and mitochondrial cytochrome oxidase I genes ( $m t C O I)$ (Chu et al., 2010a), were separately maintained on virus-free tomato plants in insectproof cages in a greenhouse. Encarsia formosa was provided by the Beneficial Insects Research Center, Shandong Academy of
Agricultural Sciences in China; the parasitoid had been reared on nymphs of Trialeurodes vaporariorum (Westwood) for $>$ 10 years.

\section{Encarsia formosa's parasitism on B. tabaci $Q$ and $B$ Biotypes under in Vitro and Semi-natural Conditions}

Selection and oviposition of $E$. formosa on $\mathrm{HQ}$ vs. $\mathrm{HB}$ or VQ vs. VB were compared under in vitro conditions in the laboratory. $\mathrm{HQ}$ and $\mathrm{HB}$ refer to virus-free plants infested with 3rd-instar nymphs of $B$. tabaci $\mathrm{Q}$ or $\mathrm{B}$. VQ and VB refer to virus-infected plants infested with 3rd-instar nymphs of B. tabaci Q or B. TYLCV-infected or TYLCV-free tomato leaves were infested with 30 3rd-instar nymphs of $B$. tabaci biotype Q or B, and in vitro parasitism was assessed as previously described (Liu et al., 2016). In brief, the leaves infested by 3rd-instar nymphs of $B$. tabaci biotype $\mathrm{Q}$ or $\mathrm{B}$ were detached from the TYLCV-free or TYLCV-infected plants. The leaf petioles were wrapped in cotton wool saturated with distilled water. Each treatment pair (HQ vs. $\mathrm{HB}$ and VQ vs. VB) was placed in plastic Petri dishes (diameter $8.5 \mathrm{~cm}$, height $1.5 \mathrm{~cm}$, two leaves per dish). A filter paper disk saturated with distilled water was also placed beneath each leaf. Newly emerged $E$. formosa females (1 day old; wasps: nymphs $=1: 30$ ) were subsequently released in the center of each Petri dishes between the two leaves and were carefully removed after $24 \mathrm{~h}$. About $8-10$ days later, the number of nymphs parasitized by wasps was recorded. Each comparison was carried out for 19 replicates.

To confirm the results obtained from the in vitro experiment, a greenhouse experiment that simulated field conditions was carried out as described by Zhang et al. (2013b). Bemisia tabaci biotype $\mathrm{Q}$ or $\mathrm{B}$ adults were placed in clip-cages on the leaves of TYLCV-infected or TYLCV-free plants (four clip-cages per plant, 20 adults per clip-cage) and allowed to oviposit; after $24 \mathrm{~h}$, all of the adults were removed. About 20 days later, when most eggs had hatched and developed into 3rd-instar nymphs, one plant of each treatment pair (HQ vs. $\mathrm{HB}$ and $\mathrm{VQ}$ vs. $\mathrm{VB}$ ) was placed in a ventilated cage $(88 \times 60 \times 79 \mathrm{~cm})$; the two plants in each cage were $50 \mathrm{~cm}$ apart. Newly emerged $E$. formosa females (1 day old; wasps: nymphs $=1: 30$ ) were subsequently released in the center of each cage between the two plants. After $24 \mathrm{~h}$, we carefully checked the tomato leaves and removed the parasitoids by using a small suction trap. The viruliferous and TYLCV-free tomato plants carrying nymphs were separately maintained in a climate chamber at $26 \pm 1{ }^{\circ} \mathrm{C}$ with $70 \pm 5 \%$ relative humidity and a 16 $\mathrm{h} / 8 \mathrm{~h}$ light/dark photoperiod. About 8-10 days later, the number of nymphs parasitized by wasps was recorded. Each comparison was replicated four times, and replications were conducted on different days to account for day-to-day variation (Zhang et al., 2013b).

\section{Olfactometer Assays}

A Y-tube olfactometer was used to assess the behavioral responses of E. formosa to the following pairs of odor sources: TYLCV-free tomato plants infested with 3rd-instar nymphs of $B$. tabaci biotype Q (HQ) or B (HB); TYLCV-infected tomato plants 
infested with 3rd-instar nymphs of B. tabaci biotype Q (VQ) or $\mathrm{B}(\mathrm{VB})$. The following combinations were also carried out to verify the absence of differences within each treatment: TYLCV-infected tomato plants without B. tabaci infestation (V) vs. V; TYLCV-free tomato plants without $B$. tabaci infestation (H) vs. H; VQ vs. VQ; VB vs.VB; HQ vs. HQ; and HB vs. HB. In all cases involving infestation, plants were infested with approximately 20 nymphs per leaf.

The olfactometer assays were carried out as previously described (Zhang et al., 2013b). In brief, an adult female of $E$. formosa (1.0-2.0 days old) was released at the base of the Y-tube and then observed continuously for $5 \mathrm{~min}$. Each female was tested only once. The selection of the two odor sources was recorded when the female had moved into one arm of the Y-tube for at least one-third of the arm's length and remained for at least $15 \mathrm{~s}$; a female that walked to the far end of the arm was also recorded as a selection. If the female did not choose within $5 \mathrm{~min}$, "no choice" was recorded. After five females were tested, odor sources were interchanged to avoid any influence of asymmetries in the set-up system. The Y-tube was replaced with a new one after it had been used to test 10 wasps. To avoid the influence of residual odor, each used tube was rinsed with $75 \%$ alcohol and kept in an oven at $180^{\circ} \mathrm{C}$ overnight. Each comparison was replicated three times, with 20 females per replicate.

\section{Collection and Analysis of Plant Volatiles}

Volatiles emitted from TYLCV-infected or TYLCV-free tomato plants infested by nymphs of $B$. tabaci biotype Q or B were collected and analyzed as described previously (Wei et al., 2007; Chen et al., 2017). The potted plants, which were carefully wrapped in aluminum foil with only the above-ground green part exposed, were placed in collection bags (one plant per bag) with a gas inlet and a gas outlet. Purified and humidified air at $300 \mathrm{~mL}$ $\mathrm{min}^{-1}$ was pumped into each bag through the inlet. A glass tube filled with $0.1 \mathrm{~g}$ of PoraPak Q (80/100-mesh; Waters, USA) was used to trap plant volatiles for $4 \mathrm{~h}$ at the outlet under continuous high-intensity sodium-halide light. Volatiles were collected from four replicate plants per treatment.

The trapped volatile samples were eluted from the PoraPak $\mathrm{Q}$ with $800 \mu \mathrm{L}$ of high-performance liquid chromatography (HPLC)-grade methylene chloride (Tedia Company, Fairfield, Ohio, USA); an internal standard $(10 \mu \mathrm{L}$ of $20 \mathrm{ng} / \mu \mathrm{L}$ of n-octane) was added to each sample for quantification of relative compound amounts. A 1- $\mu \mathrm{L}$ sample of the solution was subjected to gas chromatography-mass spectrometry (GCMS); the gas chromatograph (GC-2010 Shimadzu, Japan) was equipped with an Agilent Technologies capillary column DB$5 \mathrm{MS}(30 \mathrm{~m} \times 0.25 \mathrm{~mm}$ ID $\times 0.25 \mu \mathrm{m}$ film thickness $)$ The temperature program was as follows: the initial oven temperature was kept at $40^{\circ} \mathrm{C}$ for $4 \mathrm{~min}$ and was then increased to $200^{\circ} \mathrm{C}$ at a programmed rate of $5^{\circ} \mathrm{C} \mathrm{min}^{-1}$, followed by a rate at $20^{\circ} \mathrm{C} \mathrm{min}-1$ to $280^{\circ} \mathrm{C}$. The injector temperature was maintained at $250^{\circ} \mathrm{C}$ with a constant flow rate of $1.0 \mathrm{~mL} \mathrm{~min}^{-1}$. Compounds were identified by comparison of retention times and mass spectra (NIST database and synthetic standards). The peak area of the volatile expressed as a percentage of the peak area of the internal standard was used to analysis the change of volatiles (Chen et al., 2017).

\section{Attraction Verification of $E$. formosa to Synthetic Volatiles}

A Y-tube olfactometer was used to assess the attractions of candidate volatile compounds to E. formosa females as previously described (Zhang et al., 2013b). The candidate compounds ( $\beta$-Myrcene, $\beta$-Ocimene, $\beta$-Caryophyllene, $\alpha$ Humulene, and $\beta$-Elemene) were selected based on data obtained with TYLCV-infected tomato plants infested with B. tabaci nymphs (see Results). Nine pairs of treatments were compared: Paraffin oil (CK) vs. CK, $\beta$-Myrcene $(4.350 \mathrm{ng} / \mu \mathrm{l})$ vs. $\mathrm{CK}, \beta$-Ocimene $(3.525 \mathrm{ng} / \mu \mathrm{l})$ vs. $\mathrm{CK}, \beta$-Caryophyllene (3.350 ng/ $/ \mu \mathrm{l})$ vs. CK, $\alpha$-Humulene $(1.625 \mathrm{ng} / \mu \mathrm{l})$ vs. $\mathrm{CK}, \beta$ Elemene $(0.675 \mathrm{ng} / \mu \mathrm{l})$ vs. $\mathrm{CK}$, and mixture of monoterpenes ( $\beta$-Myrcene and $\beta$-Ocimene) vs. CK, mixture of sequiterpenes ( $\beta$-Caryophyllene, $\alpha$-Humulene, and $\beta$-Elemene) vs. CK, mixture of total candidate compounds vs. CK. As indicated, paraffin oil (CK) was used as the solvent. Two streams of purified and humidified air at $300 \mathrm{ml} \mathrm{min}{ }^{-1}$ were separately passed through two glass containers containing the test volatile in paraffin oil or containing only paraffin oil as a control and into the olfactometer arms (Chen et al., 2017). The experimental method and data collection were the same as described earlier for the olfactometer assays.

\section{Statistical Analysis}

Chi-squared tests were used to analyze the Y-tube olfactometer assays (significance level: $P<0.05$ ) (Martini et al., 2014; Mauck et al., 2015). Parasitoids that did not make a choice were excluded from the analysis. Independent-sample $t$-tests were used to compare the percentage of $B$. tabaci nymphs parasitized by $E$. formosa in each treatment pair and the quantities of volatile compounds collected from TYLCV-infected or TYLCV-free tomato plants infested with nymphs of $B$. tabaci biotype $\mathrm{Q}$ or B. All proportional data were first checked for normality and were transformed when necessary to meet the assumption of normal distribution before analysis. SPSS version 19.0 (SPSS Inc., Chicago, IL, USA) was used for all statistical analysis (Liu et al., 2016).

\section{RESULTS}

\section{Encarsia formosa' s parasitism on B. tabaci $Q$ and B Biotypes under Laboratory and Semi-natural Conditions}

On tomato leaves in the laboratory, parasitism of 3rd-instar nymphs of $B$. tabaci by E. formosa females did not differ between biotype $\mathrm{Q}$ and $\mathrm{B}$ on TYLCV-free tomato plants $(P=0.834$, Figure 1A). On TYLCV-infected tomato plants, however, parasitism was significantly higher for biotype $\mathrm{Q}$ than $\mathrm{B}(P=0.031$, Figure 1B).

The results of the semi-natural experiment showed the same trends as that in the laboratory experiment. The E. formosa did not show a preference for Q or B biotype on TYLCV-free tomato 
A

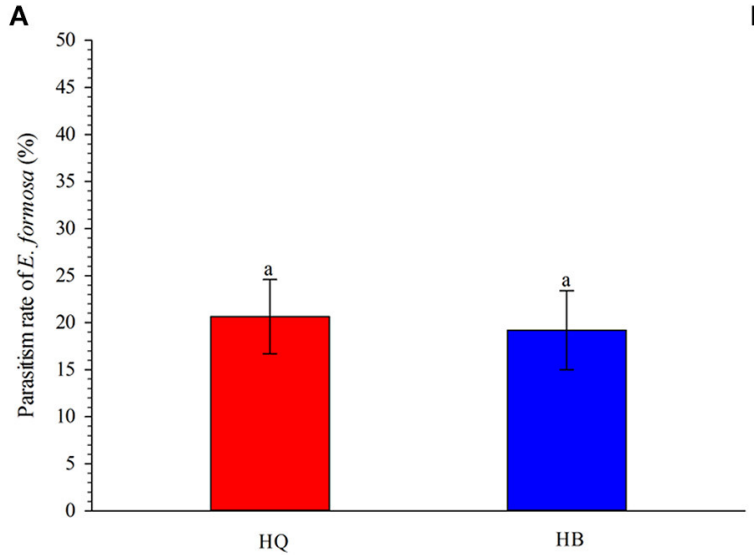

C

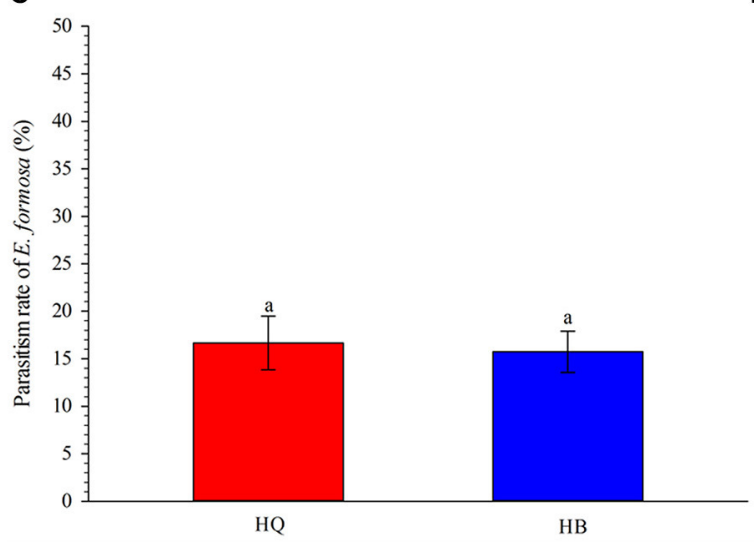

B

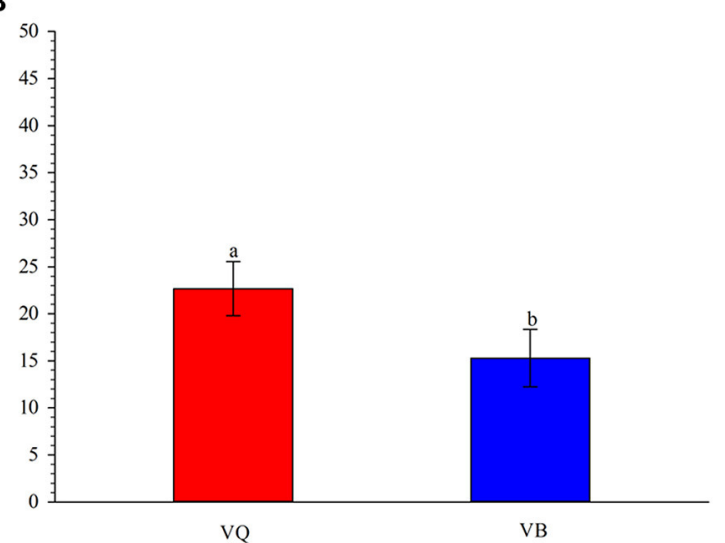

D

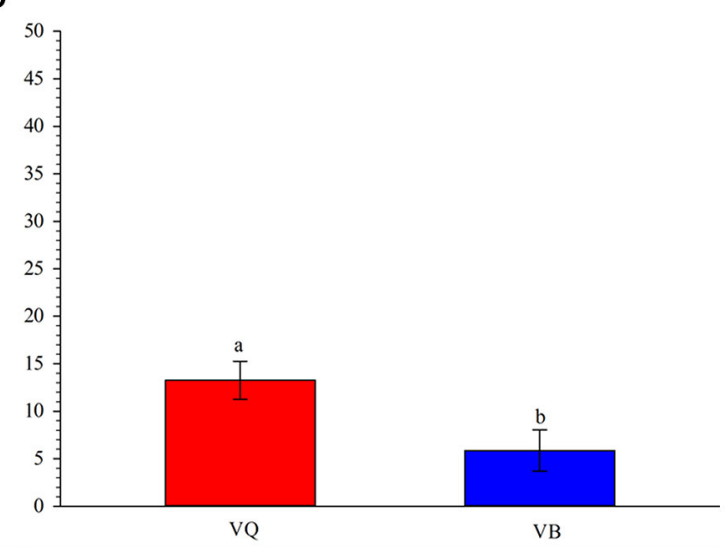

FIGURE 1 | Parasitism of 3rd-instar nymphs of Bemisia tabaci biotype Q vs. B by E. formosa on TYLCV-free (A) and TYLCV-infected (B) tomato plants under in vitro conditions and on TYLCV-free (C) and TYLCV-infected (D) plants under semi-natural conditions. HQ and HB refer to TYLCV-free plants infested with biotype Q or B. VQ and VB refer to virus-infected plants infested with biotype $Q$ or $B$. Values are means $\pm S E$. In each panel, means with different letters are significantly different according to the Tukey test at $P<0.05$.

plants $(P=0.797$, Figure 1C) but preferred biotype $\mathrm{Q}$ to biotype $\mathrm{B}$ on TYLCV-infected tomato plants $(P=0.027$, Figure 1D).

\section{Olfactometer Assays}

When tomato plants were not infected with TYLCV in Ytube olfactometer assays, the naive E. formosa females showed no significant preference for plants infested with 3rd-instar nymphs of biotype $\mathrm{Q}$ vs. biotype $\mathrm{B}$ of $B$. tabaci $(P=0.424$, Figure 2). When tomato plants were infected by TYLCV, however, E. formosa significantly preferred tomato plants infested with biotype $\mathrm{Q}$ rather than biotype $\mathrm{B}(P=0.046$, Figure 2$)$.

\section{Analysis of Plant Volatiles}

According to the analysis of the plant headspace volatiles by gas chromatography-mass spectrometry (GC-MS), all treatments produced the same 32 compounds, including monoterpenes, sequiterpenes, aldehydes, alcohols, and esters (Table 1), and differences between treatments were quantitative rather than qualitative. Quantitative analysis revealed that emissions of the monoterpenes including $\beta$-Myrcene and $\beta$-Ocimene, and the sesquiterpenes including $\beta$-Caryophyllene, $\alpha$-Humulene, and
$\beta$-Elemene were higher from TYLCV-infected plants infested with 3rd-instar nymphs of B. tabaci $Q$ than with nymphs of $B$. tabaci B. The amounts of these compounds emitted from TYLCV-free plants did not significantly differ when the plants were infested with 3 rd-instar nymphs of $B$. tabaci Q vs. B (Table 1).

\section{Attraction Verification of E. formosa to Synthetic Volatiles}

Results from olfactory test indicated that the mixture of monoterpenes, mixture of sesquiterpenes and mixture of all synthetic volatiles were all strongly attractive for E. formosa. In the meanwhile, synthetic $\beta$-Myrcene, $\beta$-Ocimene, $\beta$-Caryophyllene, and $\alpha$-Humulene attracted $E$. formosa females (Figure 3). $\beta$-Elemene did not attract significantly E. formosa females (Figure 3).

\section{DISCUSSION}

In addition to the parasitoid E. formosa, the current study included two major threats on the tomato plant: biotypes $\mathrm{Q}$ 


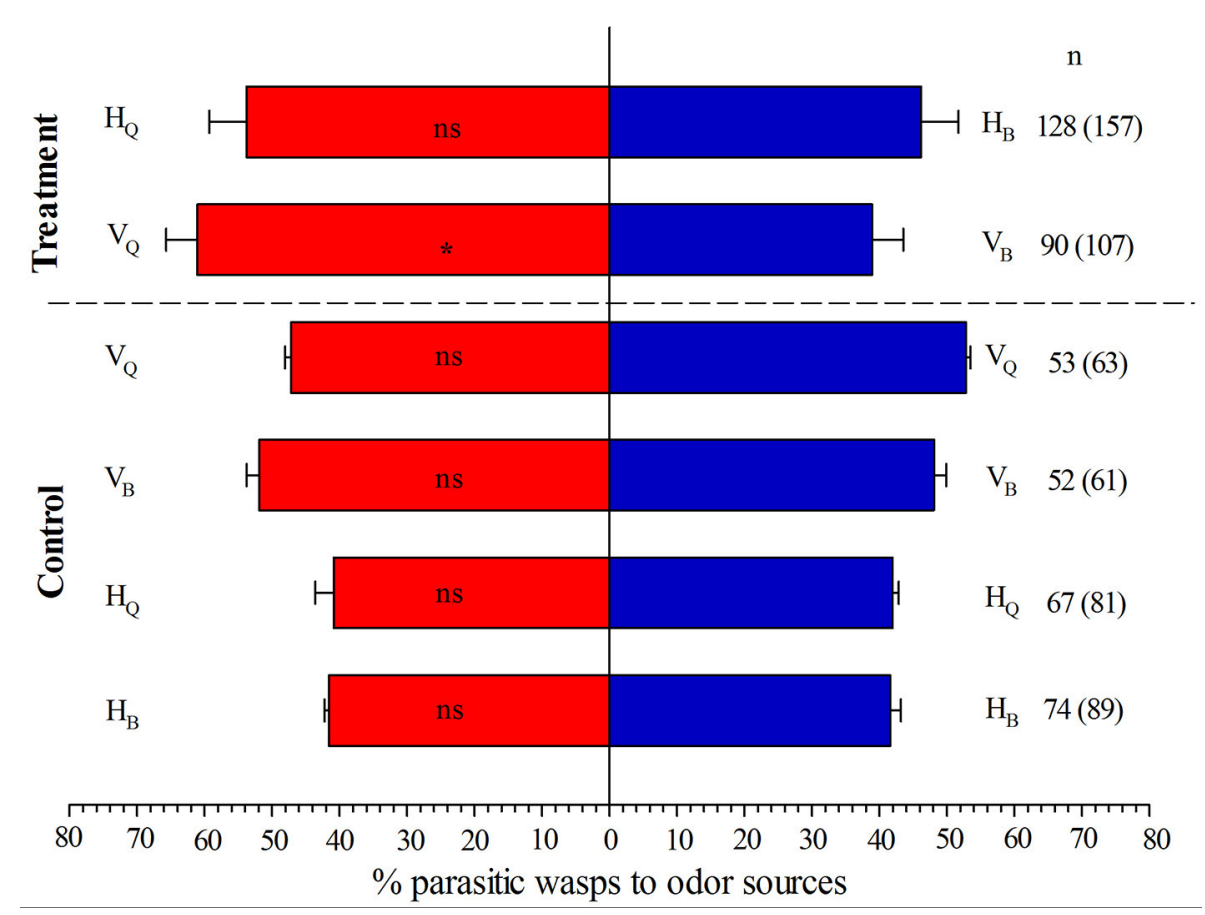

FIGURE 2 | Responses of Encarsia formosa to odor sources in a Y-tube olfactometer. Bars (means + SE) indicate the percentages of wasps choosing either of the odor sources. HQ /HB, TYLCV-free tomato plants infested with 3rd-instar nymphs of $B$. tabaci biotype Q/B; VQ/VB, TYLCV-infected tomato plants infested with 3rd-instar nymphs of $B$. tabaci biotype $Q / B$. The numbers to the right of bars indicate the number of wasps making a choice, and the total number of wasps used in the assay is indicated in parentheses. Asterisks indicate significant differences between the treatment pairs $\left(\chi^{2}\right.$ test; ${ }^{\star} P<0.05 ;$ ns, not significant).

or B of B. tabaci and the virus TYLCV. In the experiments in which the parasitoid could choose between $B$. tabaci $\mathrm{Q}$ and $\mathrm{B}$ on tomato leaves in the laboratory and on tomato plants in the greenhouse, the results proved to follow the same trend, i.e., $E$. formosa parasitized significantly more whitefly Q nymphs than B nymphs on TYLCV-infected plants but not on TYLCV-free tomato plants. The results of Y-tube olfactometer assays also showed that naive females of E. formosa exhibited a stronger olfactory preference for tomato plants infested with 3rd-instar nymphs of biotype Q than B when the plants were infected with TYLCV but not for the TYLCV-free plants. This would be helpful for the control of whiteflies populations and virus spread in the field, because the parasitoids, the higher trophic level, prefer to parasitize B. tabaci Q biotype (the prominent species in China and vectoring TYLCV widely) on TYLCV-infected plants.

Results from other systems also indicated that parasitoid attraction or parasitism rate increased when the herbivoreinfested plant was infected by a pathogen (Cardoza et al., 2003; Tack et al., 2012; Ponzio et al., 2016b). For instance, the parasitoid Cotesia glomerata was more attracted to Brassica nigra plants that were both infested by Pieris brassicae larvae and infected by Xanthononas campestris than to plants that were only infested with the larvae (Ponzio et al., 2016b). However, other reports indicated that simultaneous attack by an herbivorous insect and a pathogenic fungus did not affect parasitoid foraging
(Rostas et al., 2006), indicating that such effect on parasitism foraging may differ with different research systems (Ponzio et al., 2013).

The different responses of E. formosa to B. tabaci Q vs. $B$ on TYLCV-infected tomato plants vs. TYLCV-free tomato plants was related to quantitative (but not qualitative) differences in certain components of the volatiles emitted by the tomato plants; such differences were not evident in the volatiles emitted from TYLCV-free plants infested with B. tabaci Q vs. B. There are also other studies indicated that quantitative differences in volatiles released from plant could alter parasitoid behavior (McCormick et al., 2012; Ponzio et al., 2016b). For example, the olfactometer differences of parasitoids C. glomerata on different plant treatments are due to quantitative differences of released volatile compounds of Brussels sprout plants (Ponzio et al., 2016b).

In this present study, the main components of the volatiles that exhibited quantitative changes in response to simultaneous attack by TYLCV and $B$. tabaci were the terpenoids $\beta$ Myrcene, $\beta$-Ocimene, $\beta$-Caryophyllene, $\alpha$-Humulene, and $\beta$-Elemene. The quantities of these components were higher in TYLCV-infected tomato plants, but not TYLCVfree tomato plants, were infested with B. tabaci $\mathrm{Q}$ rather than B. In subsequent olfactometer assays with synthetic compounds, E. formosa was attracted to $\beta$-Myrcene, $\beta$ Ocimene, $\beta$-Caryophyllene, and $\alpha$-Humulene. $\beta$-Myrcene 
TABLE 1 | The peak area ratios of volatile components released from tomato plants infested by the 3rd-instar nymphs of $B$. tabaci.

\begin{tabular}{|c|c|c|c|c|c|c|c|}
\hline Compound & Retention time (min) & $\mathrm{H}_{\mathrm{Q}}$ (mean $\left.\pm \mathrm{SE}\right)$ & $\mathrm{H}_{\mathrm{B}}($ mean $\pm \mathrm{SE})$ & $\boldsymbol{P}$ & $\mathbf{V}_{\mathrm{Q}}($ mean $\pm \mathrm{SE})$ & $\mathbf{V}_{\mathrm{B}}($ mean $\pm \mathrm{SE})$ & $P$ \\
\hline Methyl-Benzene & 5.046 & $2.67 \pm 0.16 a$ & $2.11 \pm 0.24 a$ & 0.099 & $2.18 \pm 0.11 a$ & $1.84 \pm 0.16 a$ & 0.145 \\
\hline Hexanal & 6.104 & $0.21 \pm 0.33 a$ & $0.29 \pm 0.05 a$ & 0.183 & $0.20 \pm 0.03 a$ & $0.14 \pm 0.02 a$ & 0.101 \\
\hline 1-Octene & 7.322 & $0.37 \pm 0.02 a$ & $0.37 \pm 0.01 a$ & 0.721 & $0.26 \pm 0.03 a$ & $0.22 \pm 0.02 a$ & 0.260 \\
\hline Mthyl-Benzene & 7.994 & $0.50 \pm 0.07 a$ & $0.47 \pm 0.08 a$ & 0.755 & $0.28 \pm 0.03 a$ & $0.25 \pm 0.02 a$ & 0.369 \\
\hline O-Xylene & 9.08 & $0.45 \pm 0.06 a$ & $0.43 \pm 0.07 a$ & 0.836 & $0.25 \pm 0.02 a$ & $0.22 \pm 0.01 a$ & 0.203 \\
\hline$\alpha$-Pinene & 10.53 & $9.96 \pm 0.38 a$ & $9.75 \pm 1.44 a$ & 0.733 & $12.35 \pm 2.77 a$ & $9.31 \pm 0.76 a$ & 0.238 \\
\hline$\beta$-Cymene & 11.875 & $11.61 \pm 0.54 a$ & $10.13 \pm 1.17 a$ & 0.235 & $10.26 \pm 1.37 a$ & $9.47 \pm 1.49 a$ & 0.703 \\
\hline$\beta$-Pinene & 12.081 & $0.43 \pm 0.03 a$ & $0.33 \pm 0.06 a$ & 0.109 & $0.52 \pm 0.10 a$ & $0.32 \pm 0.04 a$ & 0.086 \\
\hline$\beta$-Myrcene & 12.545 & $1.15 \pm 0.11 \mathrm{a}$ & $0.87 \pm 0.10 a$ & 0.087 & $1.79 \pm 0.15 a$ & $1.10 \pm 0.05 b$ & 0.003 \\
\hline$(+)$-4-Carene & 12.84 & $50.19 \pm 2.89 a$ & $43.17 \pm 6.76 a$ & 0.314 & $44.25 \pm 9.16 a$ & $41.45 \pm 3.49 a$ & 0.072 \\
\hline I-Phellandrene & 13.088 & $16.98 \pm 1.22 \mathrm{a}$ & $14.00 \pm 2.41 a$ & 0.259 & $11.61 \pm 0.83 a$ & $14.75 \pm 1.30 \mathrm{a}$ & 0.069 \\
\hline$(+)$-2-Carene & 13.453 & $3.36 \pm 0.25 a$ & $2.87 \pm 0.55 a$ & 0.392 & $2.79 \pm 0.49 a$ & $3.10 \pm 0.33 a$ & 0.607 \\
\hline A & 13.719 & $1.34 \pm 0.07 a$ & $1.11 \pm 0.13 a$ & 0.105 & $1.54 \pm 0.23 a$ & $1.02 \pm 0.10 a$ & 0.080 \\
\hline$\beta$-Phellandrene & 13.926 & $210.95 \pm 15.22 a$ & $187.68 \pm 28.69 a$ & 0.457 & $189.09 \pm 14.63 a$ & $158.75 \pm 18.55 a$ & 0.228 \\
\hline$\beta$-Ocimene & 14.469 & $0.20 \pm 0.02 a$ & $0.19 \pm 0.03 a$ & 0.707 & $0.21 \pm 0.05 a$ & $0.098 \pm 0.01 b$ & 0.037 \\
\hline$B$ & 14.843 & $0.73 \pm 0.06 a$ & $0.58 \pm 0.11 a$ & 0.237 & $0.47 \pm 0.04 a$ & $0.55 \pm 0.03 a$ & 0.147 \\
\hline$\alpha$-Terpinolene & 15.731 & $0.74 \pm 0.07 a$ & $0.65 \pm 0.14 a$ & 0.517 & $0.82 \pm 0.16 a$ & $0.49 \pm 0.07 a$ & 0.083 \\
\hline Tridecane & 16.227 & $0.33 \pm 0.01 a$ & $0.31 \pm 0.02 a$ & 0.393 & $0.15 \pm 0.04 a$ & $0.06 \pm 0.03 a$ & 0.109 \\
\hline Nonanal & 16.381 & $0.40 \pm 0.02 a$ & $0.36 \pm 0.01 a$ & 0.053 & $0.43 \pm 0.07 a$ & $0.24 \pm 0.07 a$ & 0.068 \\
\hline Naphthalene & 18.829 & $1.47 \pm 0.14 a$ & $1.05 \pm 0.16 a$ & 0.066 & $0.58 \pm 0.04 a$ & $0.51 \pm 0.04 a$ & 0.323 \\
\hline Decanal & 19.503 & $0.10 \pm 0.01 a$ & $0.08 \pm 0.01 a$ & 0.09 & $0.07 \pm 0.01 a$ & $0.06 \pm 0.02 a$ & 0.923 \\
\hline C & 21.818 & $0.07 \pm 0.01 a$ & $0.06 \pm 0.01 a$ & 0.327 & $0.42 \pm 0.04 a$ & $0.42 \pm 0.05 a$ & 0.963 \\
\hline Methyl-naphthalene & 22.085 & $0.29 \pm 0.01 a$ & $0.22 \pm 0.03 a$ & 0.075 & $0.19 \pm 0.02 a$ & $0.14 \pm 0.01 a$ & 0.053 \\
\hline $\mathrm{D}$ & 22.353 & $0.17 \pm 0.03 a$ & $0.12 \pm 0.02 a$ & 0.2 & $0.18 \pm 0.04 a$ & $0.09 \pm 0.02 a$ & 0.078 \\
\hline Tridecanol & 22.678 & $0.09 \pm 0.01 a$ & $0.1 \pm 0.01 a$ & 0.114 & $0.11 \pm 0.01 a$ & $0.08 \pm 0.01 a$ & 0.590 \\
\hline$\beta$-Elemene & 23.206 & $0.16 \pm 0.02 a$ & $0.18 \pm 0.03 a$ & 0.62 & $0.27 \pm 0.05 a$ & $0.15 \pm 0.02 b$ & 0.035 \\
\hline Tetradecane & 24.934 & $0.23 \pm 0.01 a$ & $0.22 \pm 0.02 a$ & 0.906 & $0.25 \pm 0.03 a$ & $0.31 \pm 0.04 a$ & 0.221 \\
\hline$\beta$-Caryophyllene & 25.494 & $0.84 \pm 0.06 a$ & $0.72 \pm 0.13 a$ & 0.421 & $1.34 \pm 0.12 a$ & $0.34 \pm 0.17 b$ & 0.001 \\
\hline$\alpha$-Humulene & 26.416 & $0.39 \pm 0.03 a$ & $0.35 \pm 0.06 a$ & 0.574 & $0.65 \pm 0.06 a$ & $0.33 \pm 0.04 b$ & 0.001 \\
\hline Dibutyl phthalate & 37.637 & $1.70 \pm 0.07 a$ & $1.51 \pm 0.05 a$ & 0.053 & $0.66 \pm 0.06 a$ & $0.53 \pm 0.04 a$ & 0.880 \\
\hline$E$ & 43.442 & $0.36 \pm 0.03 a$ & $0.32 \pm 0.03 a$ & 0.444 & $0.34 \pm 0.06 a$ & $0.25 \pm 0.04 a$ & 0.234 \\
\hline Squalene & 46.037 & $0.33 \pm 0.05 a$ & $0.38 \pm 0.03 a$ & 0.374 & $0.35 \pm 0.05 a$ & $0.31 \pm 0.05 a$ & 0.877 \\
\hline
\end{tabular}

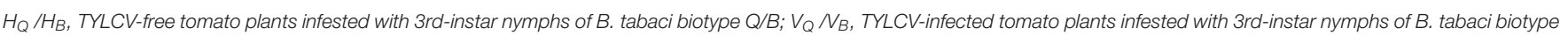

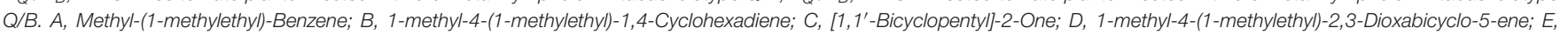

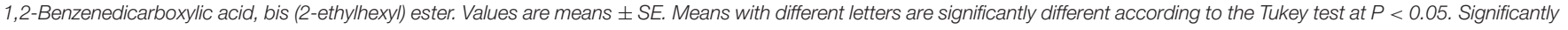
different pairs are in bold.

has been proved to strongly attract E. formosa adult (Zhang et al., 2013b). Because odors emitted by plants are mixtures of volatile compounds, a complete behavioral response of associated organisms is more likely to be elicited by multiple compounds than by single compounds (Li et al., 2014). Consistent with that view, E. formosa was strongly attracted to the mixture of $\beta$-Myrcene and $\beta$-Ocimene, the mixture of $\beta$-Caryophyllene, $\alpha$-Humulene, and $\beta$-Elemene, and the total mixture.

In addition, plants will attempt to defend themselves by activating the salicylic acid (SA), jasmonic acid (JA), and ethylene (ET) signaling pathways, when threatened by herbivores or pathogens (Ponzio et al., 2016b; Su et al., 2016). Feeding by $B$. tabaci B biotype nymphs could induce SA defenses and suppress JA defenses of Arabidopsis (Arabidopsis thaliana) plants (Zarate et al., 2007; Zhang et al., 2013a). Previous studies found that challenges by $B$. tabaci Q or B adults have different effects on plant defenses, and that TYLCV infection alters the plant's defense response to B. tabaci (Shi et al., 2013, 2014). Moreover, TPS7 encoding an enzyme that catalyzes the formation of $\beta$-Myrcene, TPS12 encoding an enzyme that catalyzes the formation of the sesquiterpenes $\beta$-Caryophyllene and $\alpha$-Humulene, and TPS5 (which encodes monoterpenes) are important terpene synthase (TPS) genes in tomato and are induced by JA or SA treatment (Vasiliki Falara et al., 2011; Simon Zebelo et al., 2014). Therefore, it is speculated that feeding by B. tabaci Q vs. B nymphs on TYLCV-infected tomato plants may activate different defense singling pathways, altering the expression of SA-regulated and JA-regulated genes that encode volatile terpenes and thereby affecting E. formosa attraction and parasitism (Bruce et al., 2008; 


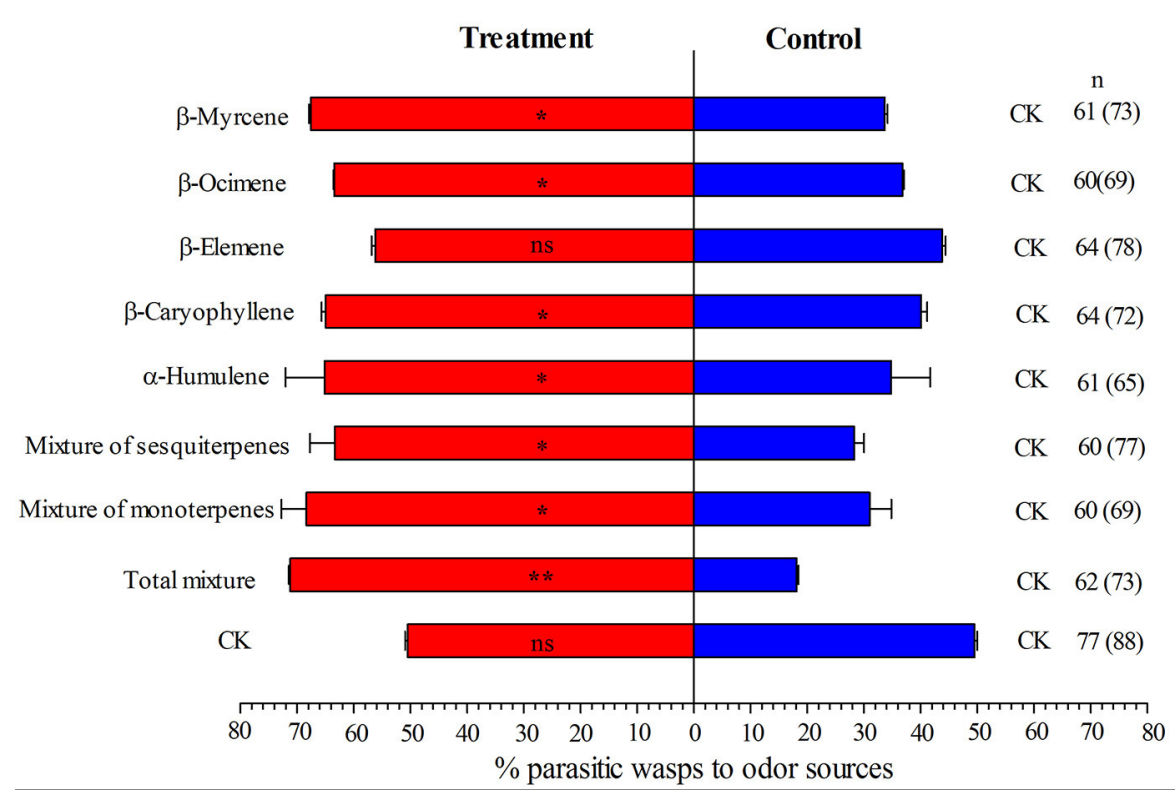

FIGURE 3 | Responses of Encarsia formosa to synthetic volatiles and paroline oil (CK) in a Y-tube olfactometer. Bars (means + SE) indicate the percentages of wasps choosing either of the odor sources. The numbers to the right of bars indicate the number of wasps making a choice, and the total number of wasps used in the assay is indicated in parentheses. Asterisks indicate significant differences between the treatment pairs (chi-square test; ${ }^{\star} P<0.05$; ${ }^{* \star} P<0.001$; ns, not significant).

Zhang et al., 2013a,b; Wu et al., 2017). This possibility needs more additional and deeper studies.

In conclusion, TYLCV-infected plants infested with the $B$. tabaci $\mathrm{Q}$ nymphs were significantly more attractive to $E$. formosa than TYLCV-infected plants infested with B. tabaci B nymphs. The difference in attraction was associated with increased quantities of $\beta$-Myrcene, $\beta$-Ocimene, $\beta$-Caryophyllene, and $\alpha$ Humulene in TYLCV-infected plants infested with B. tabaci Q nymphs.

\section{AUTHOR CONTRIBUTIONS}

XL designed and performed the experiments, wrote and revised the manuscript. GC conceived the idea, and performed the experiments. SW conceived the idea and reviewed the manuscript. YZ, WX, and QW coordinated and designed the study. All the authors have read and approved the final manuscript.

\section{REFERENCES}

Brown, J. K., and Czosnek, H. (2002). Whitefly transmission of plant viruses. Adv. Bot. Res. 36, 65-76. doi: 10.1016/S0065-2296(02)36059-2

Bruce, T. J. A., Matthes, M. C., Chamberlain, K., Woodcock, A. M., Mohib, A., Webster, B., et al. (2008). Cis-Jasmone induces Arabidopsis genes that affect the chemical ecology of multitrophic interactions with aphids and their parasitoids. Proc. Natl. Acad. Sci. U.S.A. 105:4553-4558. doi: 10.1073/pnas.0710305105

Cardoza, Y. J., Teal, P. E. A., and Tumlinson, J. H. (2003). Effect of peanut plant fungal infection on oviposition preference by Spodoptera exigua and on hostsearching behavior by Cotesia marginiventris. Environ. Entomol. 32, 970-976. doi: 10.1603/0046-225X-32.5.970

\section{FUNDING}

This work was supported by the National Natural Science Foundation of China (31572014), National Key Research and Development Plan (2017YFD0200400), and the China Agriculture Research System (CARS-25), and the Beijing Key Laboratory for Pest Control and Sustainable Control. The granting agencies had no role in study design, data collection, analysis and interpretation, decision to publish, or manuscript preparation.

\section{ACKNOWLEDGMENTS}

The authors are greatly grateful to Dr Xuguo Zhou (University of Kentucky) for the invaluable advice on the a previous version of the manuscript, Dr Xueping Zhou (Institute of Biotechnology, Zhejiang University, Hangzhou, China) for providing the infectious TYLCV clone.

Chen, G., Su, Q., Shi, S. B., Liu, X., Peng, Z. K., Zheng, H. X., et al. (2017). Odor, Not performance, dictates Bemisia tabaci's selection between healthy and virus infected plants. Front. Physiol. 8:146. doi: 10.3389/fphys.2017.00146

Chu, D., Wan, F. H., Zhang, Y. J., and Brown, J. K. (2010a). Change in the biotype composition of Bemisia tabaci in Shandong Province of China from 2005 to 2008. Environ. Entomol. 39, 1028-1036. doi: 10.1603/EN09161

Chu, D., Zhang, Y. J., and Wan, F. H. (2010b). Cryptic invasion of the exotic Bemisia tabaci biotype Q occurred widespread in Shandong province of China. Fla. Entomol. 93, 203-207. doi: 10.1653/024.093.0209

De Barro, P. J., Liu, S. S., Boykin, L. M., and Dinsdale, A. B. (2011). Bemisia tabaci: a statement of species status. Annu. Rev. Entomol. 56, 1-19. doi: 10.1146/annurev-ento-112408-085504 
Falara, V., Akhtar, T. A., Nguyen, T. T. H., Spyropoulou, E. A., Bleeker, P. M., Schauvinhold, I., et al. (2011). The tomato terpene synthase gene family. Plant Physiol. 157, 770-789. doi: 10.1104/pp.111.179648

Gerling, D., Alomar, O., and Arno, J. (2001). Biological control of Bemisia tabaci using predators and parasitoids. Crop Prot. 20, 779-799. doi: 10.1016/S0261-2194(01)00111-9

Ghanim, M., Sobol, I., Ghanim, M., and Czosnek, H. (2007). Horizontal transmission of begomoviruses between Bemisia tabaci biotypes. Arthropod Plant Interact. 1, 195-204. doi: 10.1007/s11829-007-9018-Z

Grille, G., Lorenzo, M. E., Burla, J. P., Franco, J., and Basso, C. (2012). Parasitoid niches of Encarsia formosa and Encarsia lycopersici (Hymenoptera: Aphelinidae) exploiting Trialeurodes vaporariorum (Hemiptera: Aleyrodidae). Fla. Entomol. 95, 1024-1030. doi: 10.1653/024.095.0431

Jones, D. R. (2003). Plant viruses transmitted by whiteflies. Eur. J. Plant Pathol. 109, 195-219. doi: 10.1023/A:1022846630513

Li, S. J., Ren, S. L., Xue, X., Ren, S. X., Cuthbertson, A. G. S., van Dam, N. M., et al. (2014). Efficiency of plant induced volatiles in attracting Encarsia formosa and Serangium japonicum, two dominant natural enemies of whitefly Bemisia tabaci in China. Pest Manag. Sci. 70, 1604-1610. doi: 10.1002/ps.3749

Liu, T. X., Stansly, P. A., and Gerling, D. (2015). Whitefly parasitoids: distribution, life history, bionomics, and utilization. Annu. Rev. Entomol. 60, 273-292. doi: 10.1146/annurev-ento-010814-021101

Liu, X. Y., Xiang, W. S., Jiao, X. G., Zhang, Y. J., Xie, W., Wu, Q. J., et al. (2014). Effects of plant virus and its insect vector on Encarsia formosa, a biocontrol agent of whiteflies. Sci. Rep. 4:5926. doi: 10.1038/srep05926

Liu, X., Zhang, Y. J., Xie, W., Wu, Q. J., and Wang, S. L. (2016). The suitability of biotypes Q and B of Bemisia tabaci (Gennadius) (Hemiptera: Aleyrodidae) at different nymphal instars as hosts for Encarsia formosa Gahan (Hymenoptera: Aphelinidae) PeerJ. 4:e1863. doi: 10.7717/peerj.1863

Martini, X., Pelz-Stelinski, K. S., and Stelinski, L. L. (2014). Plant pathogen-induced volatiles attract parasitoids to increase parasitism of an insect vector. Front. Ecol. Evol. 2:8. doi: 10.3389/fevo.2014.00008

Mauck, K. E., De Moraes, C. M., and Mescher, M. C. (2015). Infection of host plants by Cucumber mosaic virus increases the susceptibility of Myzus persicae aphids to the parasitoid Aphidius colemani. Sci. Rep. 5:10963. doi: 10.1038/srep10963

McCormick, C. A., Unsicker, S. B., and Gershenzon, J. (2012). The specificity of herbivore-induced plant volatiles in attracting herbivore enemies. Trends Plant Sci. 17:303. doi: 10.1016/j.tplants.2012.03.012

Ning, W. X., Shi, X. B., Liu, B. M., Pan, H. P., Wei, W. T., Zeng, Y., et al. (2015). Transmission of tomato yellow leaf curl virus by Bemisia tabaci as affected by whitefly sex and biotype. Sci. Rep. 5:10744. doi: 10.1038/srep10744

Pan, D., Li, Y. X., Luan, J. B., Liu, S. S., and Liu, Y. Q. (2014). Olfactory responses of the whitefly Bemisia tabaci and its parasitoid Eremocerus hayati to tobacco infected by the Tomato yellow leaf curl China virus. Chin. J. Appl. Entomol. 51, 60-66. doi: 10.7679/j.issn.2095-1353.2014.007

Pan, D., Wang, L. L., Liu, S. S., Li, Y. X., and Liu, Y. Q. (2013). Effects of begomovirus infection of tomato plants on leaf trichome densityz and foraging performance and fitness of Eretmocerus hayati (Hymenoptera: Aphelinidae), a parasitoid of the whitefly, Bemisia tabaci (Hemiptera: Aleyrodidae). Acta Entomol. Sin. 56, 644-651. doi: 10.16380/j.kcxb.2013.06.006

Pan, H. P., Chu, D., Ge, D. Q., Wang, S. L., Wu, Q. J., Xie, W., et al. (2011). Further spread of and domination by Bemisia tabaci biotype Q on field crops in China. J. Econ. Entomol. 104, 978-985. doi: 10.1603/EC11009

Pan, H. P., Chu, D., Yan, W. Q., Su, Q., Liu, B. M., Wang, S. L.,et al. (2012). Rapid spread of Tomato yellow leaf curl virus in China is aided differentially by two invasive whiteflies. PLoS ONE 7:e34817. doi: 10.1371/journal.pone.0034817

Ponzio, C., Cascone, P., Cusumano, A., Weldegergis, B. T., Fatouros, N. E., Guerrieri, E., et al. (2016a). Volatile-mediated foraging behaviour of three parasitoid species under conditions of dual insect herbivore attack. Anim. Behav. 111, 197-206. doi: 10.1016/j.anbehav.2015.10.024

Ponzio, C., Gols, R., Pieterse, C. M. J., and Dicke, M. (2013). Ecological and phytohormonal aspects of plant volatile emission in response to single and dual infestations with herbivores and phytopathogens. Funct. Ecol. 27, 587-598. doi: 10.1111/1365-2435.12035

Ponzio, C., Weldegergis, B. T., Dicke, M., and Gols, R. (2016b). Compatible and incompatible pathogen-plant interactions differentially affect plant volatile emissions and the attraction of parasitoid wasps. Funct. Ecol. 30, 1779-1789. doi: 10.1111/1365-2435.12689

Rostas, M., Ton, J., Mauch-Mani, B., and Turlings, T. (2006). Fungal infection reduces herbivore-induced plant volatiles of maize but does not affect naive parasitoids. J. Chem. Ecol. 32, 1897-1909. doi: 10.1007/s10886-0069147-3

Shi, X. B., Pan, H. P., Xie, W., Wu, Q. J., Wang, S. L., et al. (2013). Plant virus differentially alters the plant's defense response to its closely related vectors. PLOS ONE 8:e83520. doi: 10.1371/journal.pone. 0083520

Shi, X. B., Pan, H. P., Zhang, H. Y., Jiao, X. G., Xie, W., Wu, Q. J., et al. (2014). Bemisia tabaci $\mathrm{Q}$ carrying tomato yellow leaf curl virus strongly suppresses host plant defenses. Sci. Rep. 4:5230. doi: 10.1038/srep05230

Su, Q., Mescher, M. C., Wang, S. L., Chen, G., Xie, W., Wu, Q. J., et al. (2016). Tomato yellow leaf curl virus differentially influences plant defence responses to a vector and a non-vector hervibore. Plant Cell Environ. 39, 597-607. doi: $10.1111 /$ pce. 12650

Tack, A. J. M., Gripenberg, S., and Roslin, T. (2012). Cross-kingdom interactions matter: fungal-mediated interactions structure an insect community on oak. Ecol. Lett. 15, 177-185. doi: 10.1111/j.1461-0248.2011.01724.x

Teng, X., Wan, F. H., and Chu, D. (2010). Bemisia tabaci biotype Q dominates other biotypes across China. Fla. Entomol. 93, 363-368. doi: 10.1653/024.093.0307

Wei, J. L., Wang, L. Z., Zhu, J. W., Zhang, S. F., Nandi, O. I., and Kang, L. (2007). Plants attract parasitic wasps to defend themselves against insect pests by releasing hexenol. PLOS ONE 9:e852. doi: 10.1371/journal.pone.0000852

Wu, D. W., Qi, T. C., Li, W. L., Tian, H. X., Gao, H., Wang, J. J., et al. (2017). Viral effector protein manipulates host hormone signaling to attract insect vectors. Cell Res. 27, 402-415. doi: 10.1038/cr.2017.2

Zarate, S. I., Kempema, L. A., and Walling, L. L. (2007). Silverleaf whitefly induces salicylic acid defenses and suppresses effectual jasmonic acid defenses. Plant Physiol. 143, 866-875. doi: 10.1104/pp.106.090035

Zebelo, S., Piorkowski, J., Disi, J., and Fadamiro, H. (2014). Secretions from the ventral eversible gland of Spodoptera exigua caterpillars activate defense related genes and induce emission of volatile organic compounds in tomato, Solanum lycopersicum. BMC Plant Biol. 14:140. doi: 10.1186/1471-222914- 140

Zhang, P. J., Li, W. D., Huang, F., Zhang, J. M., Xu, F. C., and Lu, Y. B. (2013a). Feeding by whiteflies suppresses downstream jasmonic acid signaling by eliciting salicylic acid signaling. J. Chem. Ecol. 39, 612-619. doi: 10.1007/s10886-013-0283-2

Zhang,. P. J., Xu, C. X., Zhang, J. M., and Lu, Y. B. (2013b). Phloem-feeding whiteflies can fool their host plants, but not their parasitoids. Funct. Ecol. 27, 1304-1312. doi: 10.1111/1365-2435.12132

Zheng, H. X., Xie, W., Wang, S. L., Wu, X., Zhou, Z., and Zhang, Y. (2017). Dynamic monitoring (B vs. Q) and further resistance status of Bemisia tabaci in China. Crop Prot. 94, 115-122. doi: 10.1016/j.cropro.2016.11.035

Conflict of Interest Statement: The authors declare that the research was conducted in the absence of any commercial or financial relationships that could be construed as a potential conflict of interest.

Copyright (c) 2017 Liu, Chen, Zhang, Xie, Wu and Wang. This is an open-access article distributed under the terms of the Creative Commons Attribution License (CC $B Y)$. The use, distribution or reproduction in other forums is permitted, provided the original author(s) or licensor are credited and that the original publication in this journal is cited, in accordance with accepted academic practice. No use, distribution or reproduction is permitted which does not comply with these terms. 